\title{
Magnetic anomaly patterns, fault-block tectonism and hydrocarbon related structural features in the Niger Delta basin
}

\author{
Okiwelu, A. A., Obianwu, V. I., Eze Ohara, E. and Ude, I. A. \\ Geophysics Research Unit, Department of Physics, University of Calabar, Nigeria
}

\begin{abstract}
Gridded airborne magnetic data, 3D magnetic forward models in combination with filtered maps and derivative techniques such as analytic signal and directional derivatives were used to reveal basement structure and architecture of the study area in offshore Niger Delta. The generating mechanisms of the magnetic anomalies are boundaries (fault) of basement blocks of different compositions having different physical properties (susceptibilities and remanence) and horst/graben structures with associated normal faults and extensions. The intrabasement sources exhibit anisotropic susceptibilities and depth to basement (sedimentary thickness) is between $4000 \mathrm{~m}$ to over 10,000m indicating deep depocenters. All these factors combined to influence magnetic anomaly patterns which have implications in hydrocarbon prospect target. The regional structural characteristics of the basement interpreted from the regional magnetic data sets show clear relationship between inferred rift-related basement structures and oil fields. Oil and gas discoveries appear to be located on the flanks of steep/faulted basement and on top of basement structural highs and lows. This study, therefore, is significant in understanding the petroleum system, contributes to basin modelling and can unravel areas of identical structural development in less well-explored sectors of the basin.
\end{abstract}

Keywords: Anomaly, Basement, Basin, Derivative, Fault, Hydrocarbon

\section{Introduction}

Magnetic field data play important role in detecting geological features for hydrocarbon exploration. Magnetic surveys are often undertaken prior to seismic surveys with the aim of delineating structural trends, so that seismic surveys can be designed in a cost-effective manner to maximum result [1]. The identification and mapping of the geometry, scale and nature of basement structures is critical in understanding the influence of basement during rift development, basin evolution and subsequent basin inversion [2]. In thick sedimentary terrain like the Niger delta basin, regional magnetic field data sets could be exploited in imaging the basement under the sedimentary section, particularly if magnetic sources within the sedimentary section are weaker than the basement rocks. Over the years, multinational producing oil companies have recorded high success in hydrocarbon discoveries both on and offshore Niger delta. Currently, there is drive by most investors to discover more commercial successful wells with less risk and maxima profit. Critical factors such as regional structural characteristics of the basement and the relationship between deep basement architecture and hydrocarbon target have been lacking in the delta. Therefore, in this study, our fundamental building block is the regional structural characteristics of the basement which is poorly understood in the Niger delta basin. This alternative method can strongly enhance the productive capability of the basin and lead to more discovery. Our main objective is to identify and delineate possible regional uplifted blocks (horst) and depocenters associated with faults/fractures that may facilitate the location of hydrocarbon prospect in the Niger delta.

Potential field data especially aeromagnetic surveys are used commonly to map basement structure beneath sediment cover. Thus, the Niger delta basin offers an excellent opportunity to evaluate the potential role of basement structure to hydrocarbon plays. We used the term "basement structure" as defined by Ross et al. [3], which is described as structural fabrics within the crystalline basement. Some of these are shear zones that have maintained their coherence during ductile deformation and some are faults or fault zones where coherence has been lost and slip in the brittle regime has occurred. Such structures can be identified and delineated accurately by using regional magnetic field data sets. Aeromagnetic method has been recognized as an effective tool for mapping structures within basement rocks where measured magnetic anomalies usually indicate magnetic susceptibility contrasts within the crystalline basement [4].

By integrating attribute magnetic data sets such as analytic signal, directional derivatives, residual and filtered maps in conjunction with 3D subsurface models we delineated structures and their depths which may be useful in decision making regarding the development and evaluations of oil and gas plays for the deeper parts of the Niger Delta basin and for future seismic investment. The enhanced data sets helped to identify subtle features which may be geologic boundaries that may play significant roles in exploration and production in the Niger delta. This approach facilitated the identification of faulted basement block contacts, basement shearfractured zones, intrabasement compositional changes (for example, plutons and batholith boundaries and 
igneous intrusions). These are magnetic lineament boundaries which play important roles in exploration. Fault detection in magnetic data mostly relies on identification of lineaments [5].

Ground and airborne data sets are now considered essential components of mineral exploration programmes and are increasingly being used in petroleum exploration [6]. Piskarev and Tchernyshev [7] demonstrated a spatial relationship between hydrocarbon deposits and features of magnetic and gravity field anomalies in the vicinity of oil and gas reservoirs in Western Siberia. They showed that hydrocarbon deposits coincide commonly with local magnetic and gravity minima generated by lows in basement magnetization and density. Mohammed et al. [8] stressed the importance of using surface and subsurface lineaments in the basement for delineating hydrocarbon reservoirs in Sabakyn basin, Yemen. Edgell [9] reported the control of oil and gas fields in Saudi Arabia by extentional block faulting in the crystalline Precambrian basement. Crawford et al. [10] used aeromagnetic data in the northern Wernecke Inlier to investigate fault architecture and geometry of buried crystalline basement to understand the potential control of economic deposits. Thus, a reasonable detailed basement structure map is an integral part of any regional geological or hydrocarbon evaluation process. Such a map identifies critical structural trends, the locations of the regions prominent structural prospects and the location and geometry of the hydrocarbons depocenter [11].

\section{Geology And Tectonic Framework}

The Niger Delta (fig. 1) oil province is underlain by thick deltaic deposits of Tertiary age. A new threefold lithostratigraphic subdivision is introduced for the Niger delta subsurface, comprising an upper sandy Benin formation, an intervening unit of alternating sandstone and shale named the Agbada Formation and a lower shaly Akata Formation (fig. 2). These three units extend across the whole delta and each ranges in age from early Tertiary to Recent [12]. The principal oil discoveries have been made in the Agbada Formation. The tectonic structures in the rocks of the older cycles are mainly faults and occasional folds which strike in general NW and NE while the original basement lineaments trend N-S. The NW and NE strike directions of the fracture system resulting from the breaking of the old African shield are very common in the entire continent [13]. The Cenozoic Niger Delta fills part of the Southern Nigeria sedimentary basin (fig.3). The development of the whole basin is structurally controlled by lineaments resulting from the opening of the Southern Atlantic Ocean. A NESW system defines the northwestern edge of the basin and a NW-SE system defines the northeastern edge (the Calabar hinge line) of the Niger Delta basin. The basement has subsided to allow a sediment pile of about $12 \mathrm{~km}$ maximum thickness to accumulate in complex response to depth and temperature dependent mechanical behavior of the lithosphere. Under the influence of loading the lithosphere has bent elastically to accumulate the deltaic sedimentary pile in what is only a first order description of the margin's response [14, 15].

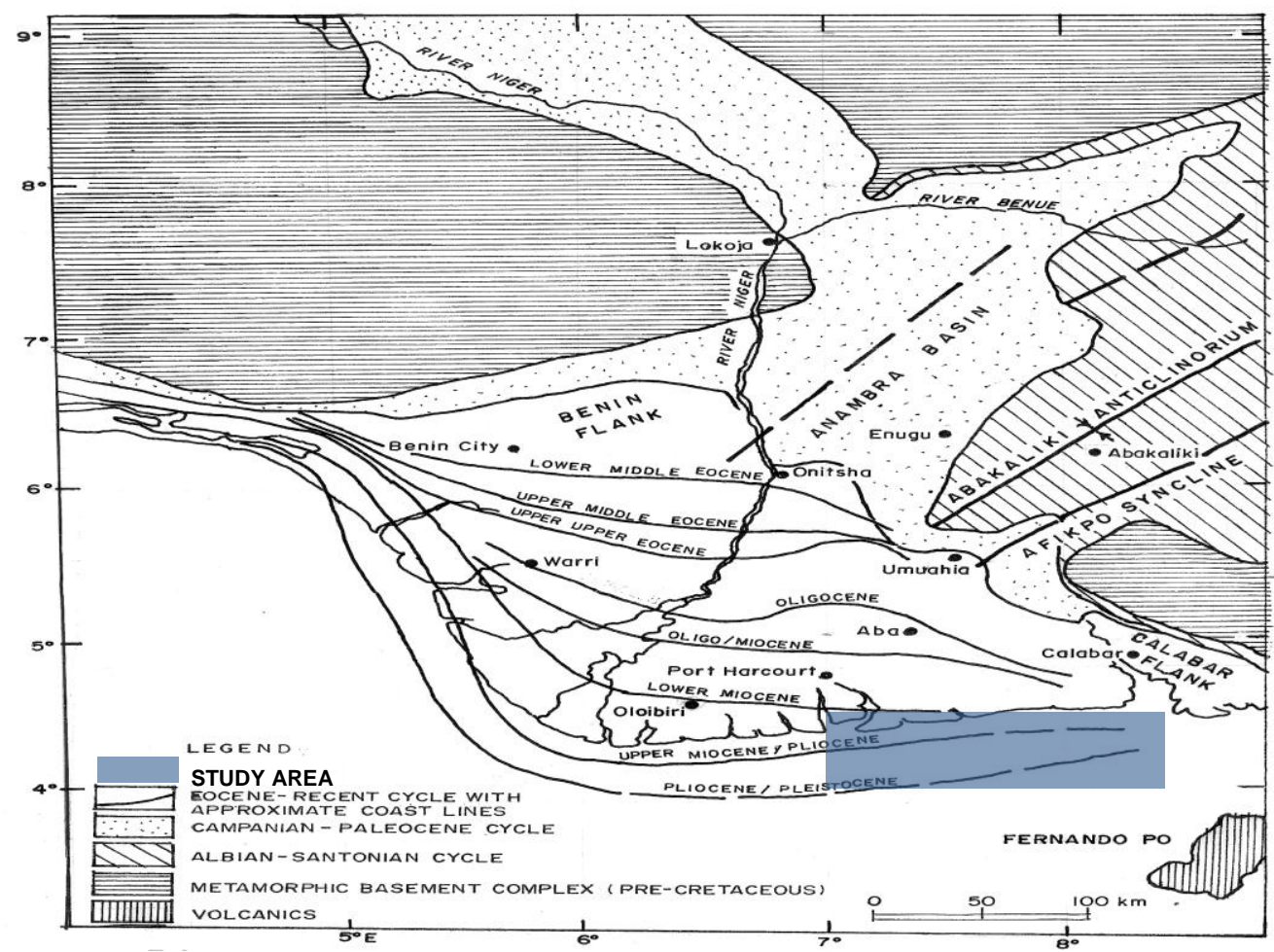

Fig. 1: General geological map of Niger Delta and environs showing the study area 


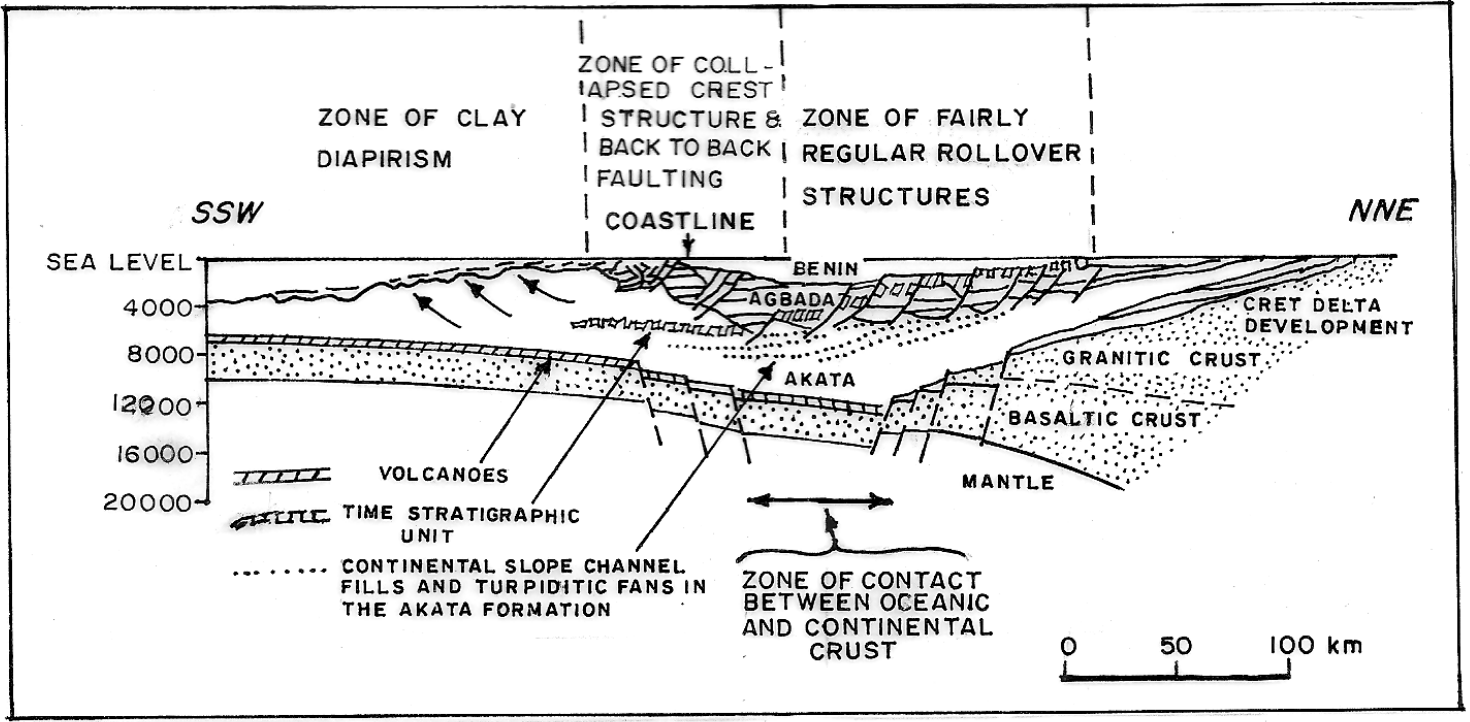

Fig. 2: Schematic dip section of the Niger Delta

Growth fault trends are recognized probably related to basement faults, but extensive shale tectonics did not occur, so that equivalent biostratigraphy and lithostratigraphy can be recognized on either side of fault trends. This delta was overwhelmed by the Paleocene Imo shale transgression which brought deep marine shales to the head of the Anambra Basin [15].

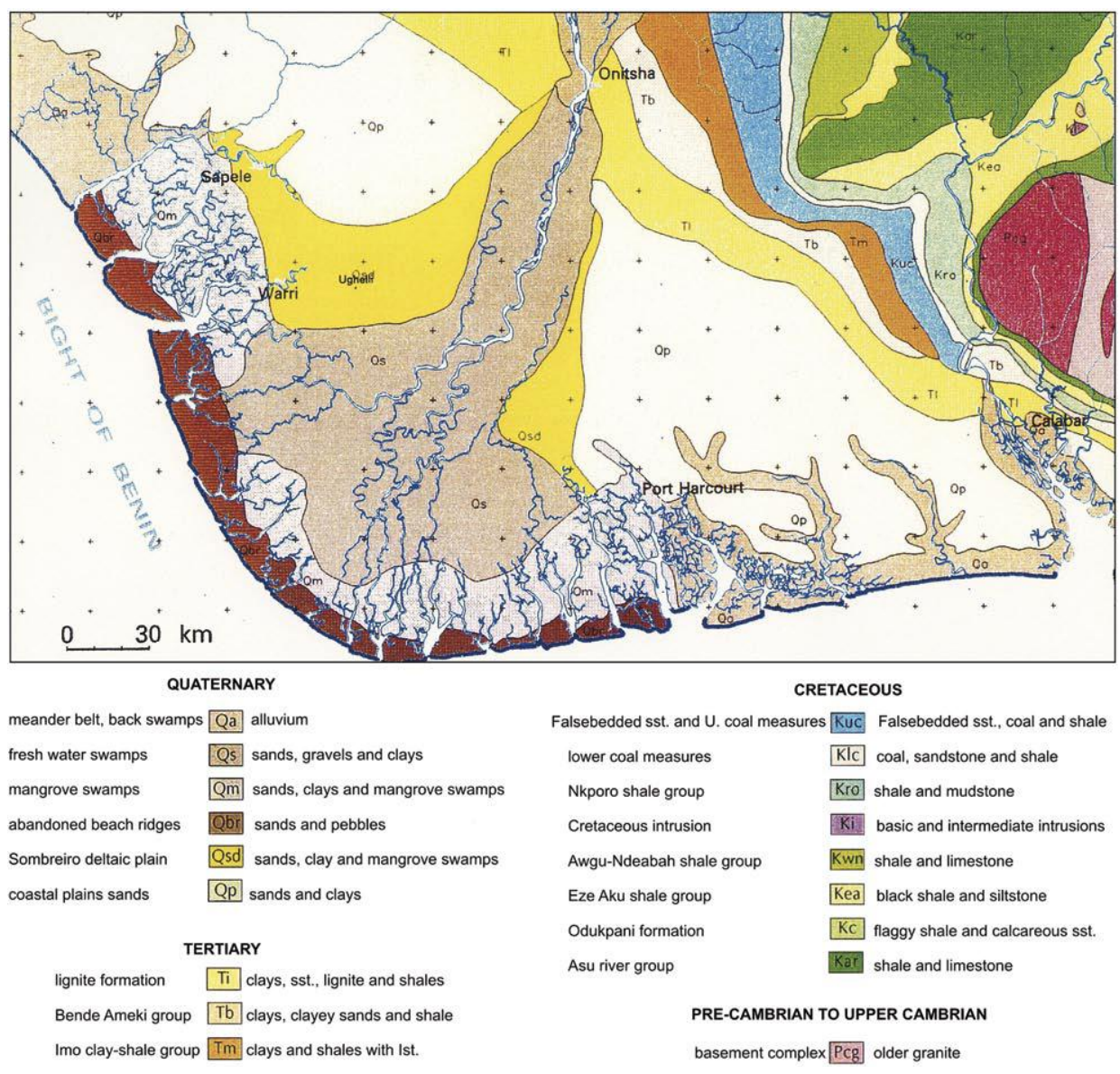

Fig.3. Geological map of the Niger Delta and environs (After Reijers, 2011)

During the Cenozoic, until the Middle Miocene, the Niger Delta grew through pulses of sedimentation over an oceanward-dipping continental basement into the Gulf of Guinea; thereafter progradation took place over a landward-dipping oceanic basement [16]. Basement tectonics related to crustal divergence and translation 
during the Late Jurassic to Cretaceous continental rifting probably determined the original site of the main river and controlled the early development of the delta [17].

The tectonic framework of the continental margin along the West Coast of equatorial Africa is controlled by Cretaceous fractures zones expressed as trenches and ridges in the deep Atlantic. The trough represents a failed arm of a rift triple junction associated with the opening of the south Atlantic [8]. In the Delta, rifting diminished altogether in the Late Cretaceous. After rifting ceased, gravity tectonics became the primary deformational process. Shale mobility induced internal deformation occurred in response to two processes. First, shale diapirs formed from loading of poorly compacted, over-pressured prodelta and delta-slope clays (Akata Formation) by the higher density delta-front sand (Agbada Formation). For any given depobelt, gravity tectonics were completed before deposition of the Benin formation and are expressed in complex structures, including shale diapirs, roll-over anticlines, collapsed growth fault crests, back-to-back features and steeply dipping closed spaced flank faults [17]. Deposition of the three formation occurred in each of the five, off-lapping Siliciclastic Sedimentation Cycle that comprises the Niger Delta. One of the most conspicuous geological features of the Niger Delta is its growth fault pattern. Almost all the oil reserves are contained in rollover structures which are associated with growth -faults. These structural features are thought to have been formed by the force of gravity acting on a thick body of sediments supplied mainly by the Niger River [19].

\section{Description Of The Magnetic Data}

The total intensity data (fig. 4) originated from part of airborne geophysical survey flown and compiled by Earth Sciences limited in 1975 on behalf of Geological survey of Nigeria. In the study area data were acquired along NE-NW ( $20^{\circ} / 200^{\circ}$ azimuth) flight lines spaced $2 \mathrm{~km}$ apart along orthogonal nominal tie lines flown at $110^{\circ} / 290^{\circ}$ azimuth, $20 \mathrm{~km}$ apart at a terrain clearance of $762 \mathrm{~m}$. The regional correction is based on International Geomagnetic Reference field model (IGRF). This correction computed the magnetic field from the outer core which was removed from the observed data. The gridding of the magnetic data sets was done using cell sizes of $1000 \mathrm{~m}$. This is adequate enough to capture the anomaly details that meet the objective of this study, while not creating artifacts in the magnetic data.

The targets of specific surveys are often small scale structures buried at shallow depth and the magnetic responses of these targets are embedded in a regional field that arises from magnetic sources that are usually larger or deeper than the targets or are located farther away. Interpretation and numerical modelling are carried out in the residual field data and the reliability of the interpretation depends to a great extent upon the success of the regional-residual separation [20].

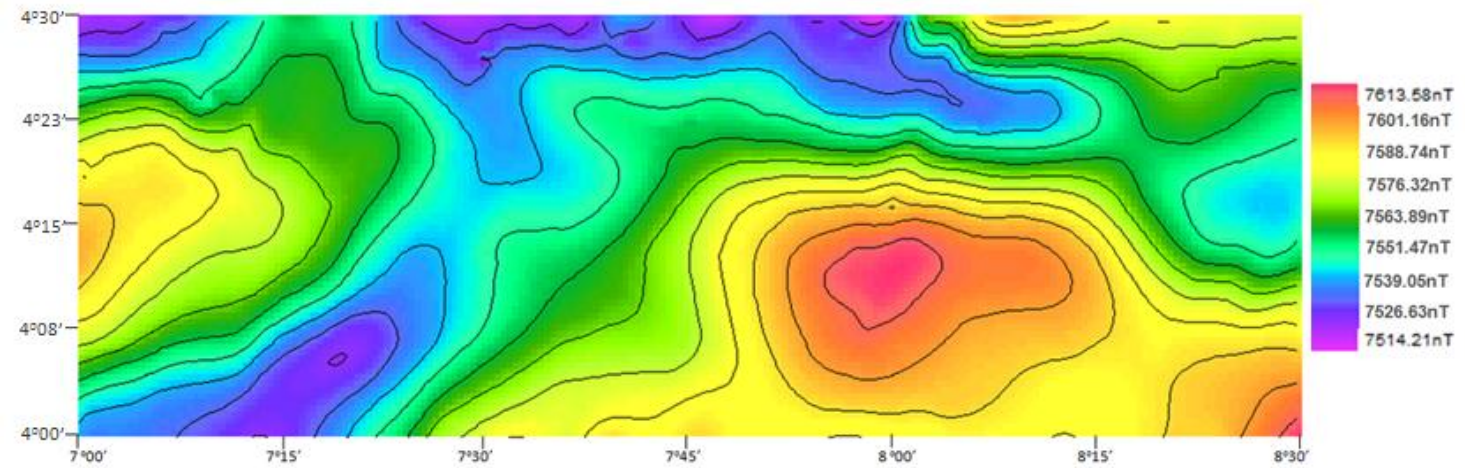

Fig.4 Total magnetic intensity data of the study area characterized by magnetic highs, lows and shear zones

Bearing in mind that magnetic data measured in geophysical surveys are the sum of magnetic fields emanating from all subsurface sources and to highlight the residual magnetic field required for the qualitative and quantitative interpretation both first and second degree polynomials (figs. 5a and 5b) were computed from the total intensity data. The identical images displayed showed that the two polynomials can adequately image the basement. 


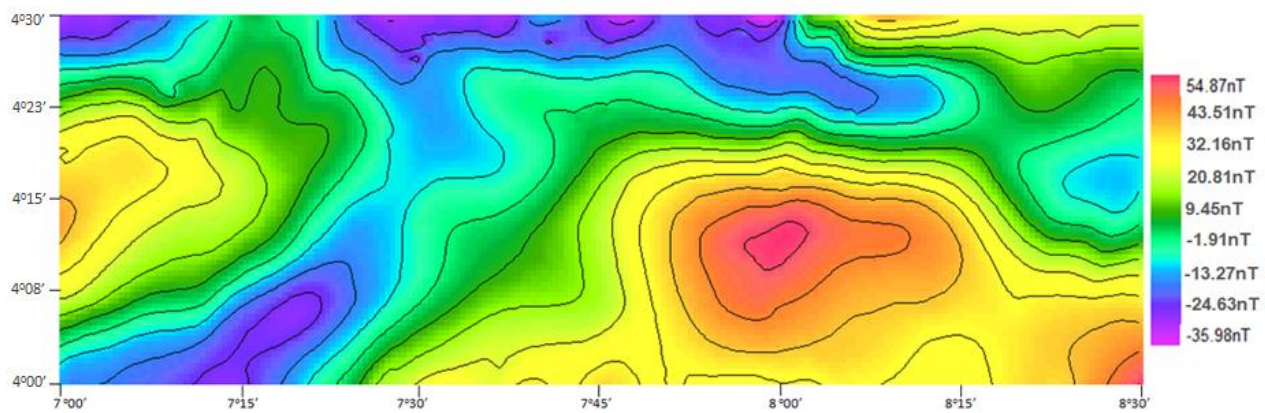

(a)

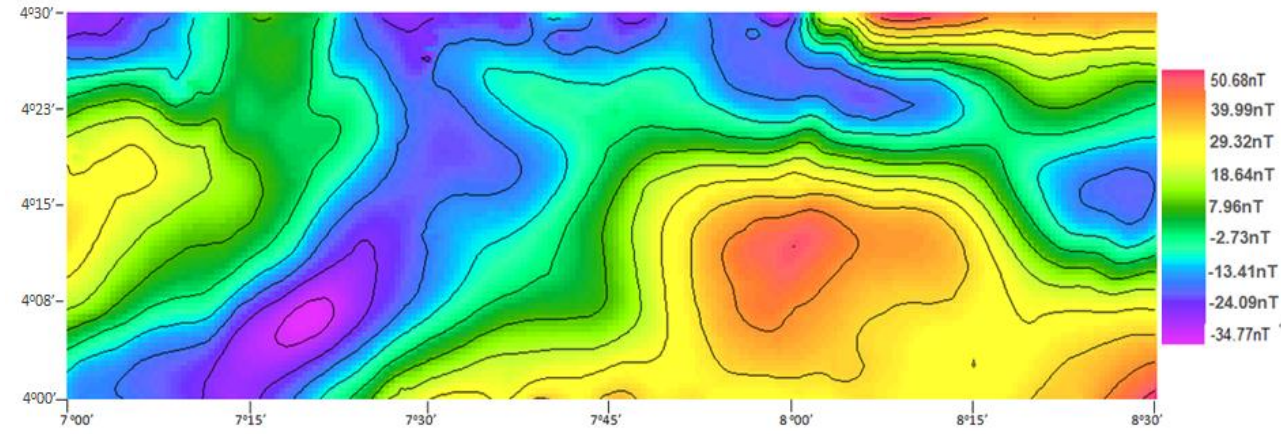

(b)

Fig.5 Residual magnetic field data computed with (a) first and (b) second degree polynomials. Linear, circular and sub-circular magnetic anomalies are well defined.

\section{Transformation Of The Magnetic Field Data}

To highlight certain features that may be useful for exploration we chose interpretational tools that show cessations, displacement or interruption of magnetic anomalies. These patterns are pointer to fault/fractures, shear zones and lithologic contact. We therefore computed analytic signal and directional derivatives fields which typically reflect block boundaries and other localized structural features. We also applied wavelength filtering that met the objective of this study. These enhancement techniques are edge detecting derivatives that enhance lateral discontinuities in total magnetic intensity grid [21 - 24] and show network of discontinuities, like lines of truncations and strike - slip faults/shear zones that aid to compartmentalize and delimit discrete anomalies that at first may appear as a confused pattern of unravellable anomalies [25].

Analytic signal maps are useful in revealing anomaly texture of potential field maps and highlight discontinuities in anomaly pattern [5]. The maxima of analytic signal are located close to the outline of magnetic and gravity sources. Analytic signal is defined as:

$$
A=\frac{\partial \Delta T}{\partial x} i+\frac{\partial \Delta T}{\partial y} j+\frac{\partial \Delta T}{\partial z} k
$$

Where $\mathrm{i}, \mathrm{j}$ and $\mathrm{k}$ are unit vectors in the $\mathrm{x}-\mathrm{y}$ - and $\mathrm{z}$ - directions respectively. The real and imaginary parts of its Fourier transform are the horizontal and vertical derivatives of $\Delta T$ (total magnetic field anomaly). The analytic signal can easily be computed in the frequency domain [26, 21]. The amplitude of analytic signal defined as:

$$
|A|^{2}=\sqrt{\left(\frac{\partial \Delta T}{\partial x}\right)^{2}+\left(\frac{\partial \Delta T}{\partial y}\right)^{2}+\left(\frac{\partial \Delta T}{\partial z}\right)^{2}}
$$

is frequently used in the interpretation of potential field data and may compliment the reduction-to-pole (RTP) and the horizontal-gradient method for edge detection particularly in regions of low latitude where remanence is high. The maxima of this amplitude function are located over magnetization contrast and their widths can be used to estimate the contact depth. Additional advantage of the analytic signal amplitude interpretation is that its shape (but not amplitude) is independent of the direction of the Earth's magnetic field and of the magnetization vector. It is also independent of the dip of the contact and of the value of magnetization [27].

Analytic signal map (fig. 6) reveals the anomaly source body edges and corners typified as basement fault block boundaries, basement lithologic contact and fault/shear zones. These structures in the analytic signal map 
are aligned in the $\mathrm{N}-\mathrm{S}$ direction suggesting that it is the best derivative to recover N-S contacts in equatorial belt where ambient field are horizontal and structures striking N-S are difficult to unravel. The N-S structures are responsible for the broad arches in the Tertiary sediments as revealed by the depth to basement map. The up arching was probably responsible for the formation of less pronounced E-W structural trends which are predictably well defined in the dy map (fig. 7). Thus, a well defined directional filter is an effective tool for highlighting subtle E-W basement trend. The edges of small circular and lenticular contours are rift-stage normal faults which are important in hydrocarbon trapping. The derative maps show that the edges of anomalies become sharper or clearer if derivative operators are applied to the magnetic data. For example, the shear zones

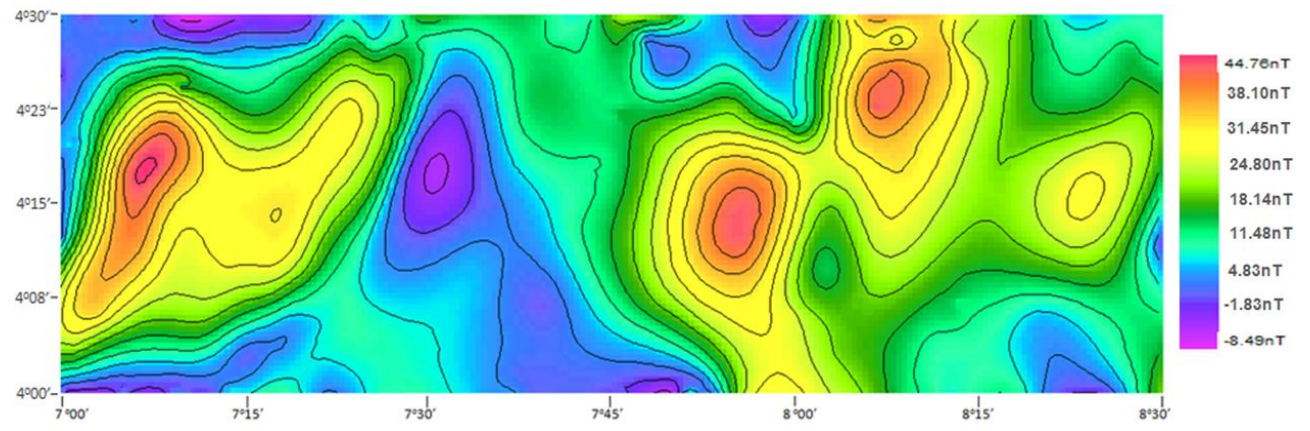

Fig. 6 Analytic signal map with the magnetic field defining a more N-S trending fabrics

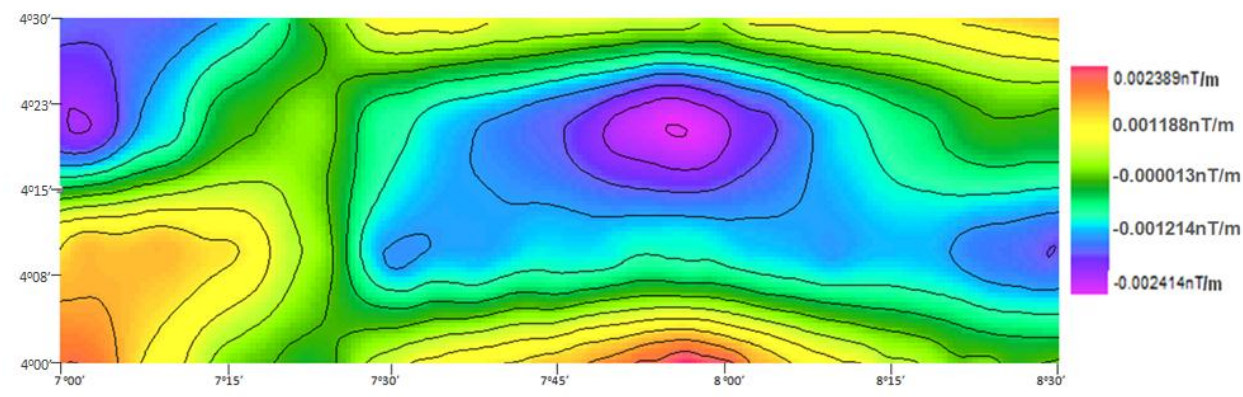

Fig.7 Derivative (dy) map showing E-W trending structures

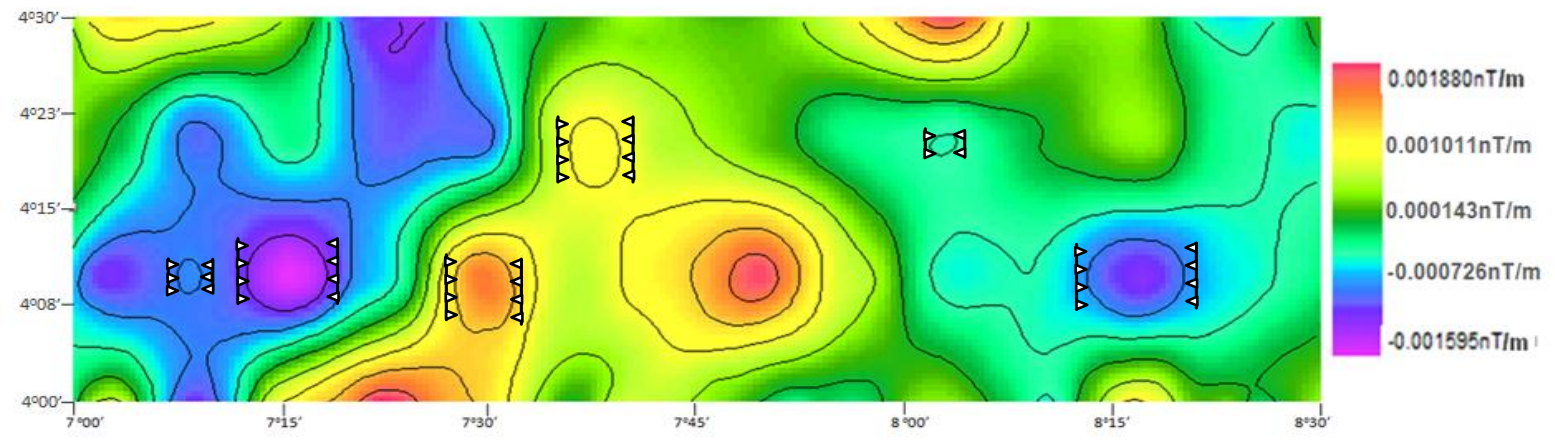

Fig.8 Derivative (dx) map showing N-S bounded basement fault-block and shear zones

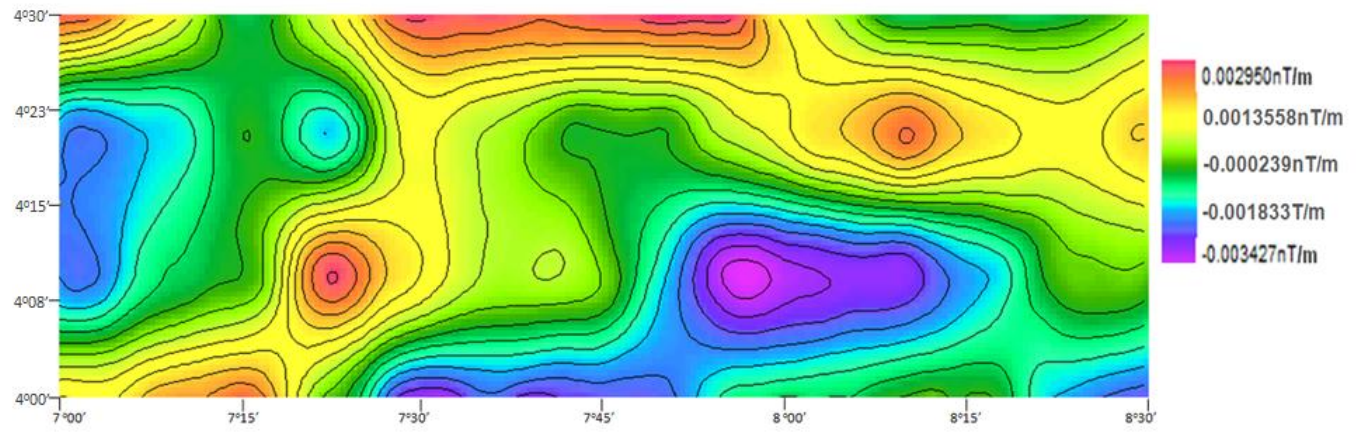

Fig. 9 First vertical derivative map delineates the boundaries of source bodies and local anomalies 
in the dx (Fig. 8) and dz (fig. 9) maps fall on magnetic gradients between magnetic highs and lows and are lineaments. These are the block boundaries of the basement fault block pattern which occur in sets of parallel to sub-parallel fractures having different strike directions. They are of distinct ages and hence created anomaly terminations and truncations which are mappable with residual aeromagnetics because of rock types and magnetic susceptibility changes across them [28]. The shear zones are basement weakness zones which were reactivated by regional stresses or later tectonic events in the Niger delta which have localized structures and have influence on the overlying stratigraphic section. The derivative data sets, therefore, made it possible to unravel additional information on the structure and composition of the basement than from the unfiltered total intensity magnetic data.

To aid interpretation and achieve our objectives of delineating basement structures relevant for exploration and to emphasize particular characteristics of the magnetic data we applied wavelength filtering based on Fourier integral transform. Fourier integral transform $T(u, v)$ of a function $t_{1}(x, y)$ is:

$$
T(u, v)=\int_{-\infty-\infty}^{+\infty+\infty} \int_{1}(x, y) e^{-2 \pi i(u x+v y)} d x d y
$$

Where $u$ and $v$ are wavenumbers associated with $x$ and $y$ coordinate axes respectively. $t_{1}(x, y)$ is the total magnetic field value known at discrete points (input data). Thus, the discrete Fourier transform:

$$
T(k, l)=\sum_{m=0}^{M-1} \sum_{n=0}^{N-1} t_{1}(m, n) e^{-2 \pi i\left(\frac{k m}{M}+\frac{L n}{N}\right)}
$$

Where $m, n$ are integers representing grid point locations in the space domain; $k, l$ are integers representing grid point locations in the frequency domain and $M, N$ are the number of rows and columns. To obtain the filtered output, $t_{2}$ in the spatial domain, the inverse Fourier transform is used and for the discrete data set, $T_{2}$ :

$$
t_{2}(m, n)=\frac{1}{M} \frac{1}{N} \sum_{K=0}^{M-1} \sum_{l=0}^{N-1} T_{2}(K, L) e^{2 \pi\left(\frac{k m}{M}+\frac{\mathrm{ln}}{N}\right)}
$$

This involves qualitative interpretation which reveals magnetic relief and magnetic textures. Magnetic relief consists primarily of anomaly amplitude and is relatively objective while magnetic texture consists of shape, size and continuity of adjacent anomaly and is more subjective [6]. Variation in geology which is a reflection of rock magnetization produce changes in texture and relief. When rock magnetization is weak, anomalies are subdued and wavelength filtering is required to reveal the change. In this study, we noted that variations in the anomaly wavelength content may be related to variable survey parameters such as flight line spacing and altitude as well as to variation in basement depth, structure and composition. False magnetic lineaments can potentially be created along boundaries of dissimilar surveys merged into a common data set. We also tried as much as possible to avoid Gibbs ringing which may be created by band pass wavelength filtering. Bandpass wavelength filtering has several drawbacks: it requires assuming the cut-off wavelength, can smear the separation due to non-vertical filter roll-off and can contaminate the data by Gibbs ringing [5]. Thus, we discarded some undesirable wavelengths and retained some wavelengths of the magnetic anomalies that highlighted geologic boundaries that play significant roles in exploration.

Fig. 10 and fig. 11 show part of the data that are characterized by short wavelength, relatively high amplitude anomalies and part that are characterized by longer wavelength anomalies. Partitioning of the magnetic data was, therefore, done using qualitative interpretation which consists of analyses of trends and linears. Thus, drawing lines on the maps dominated the early stages of this study and the commencement of qualitative phase. The transform process, therefore, highlighted relatively high frequency components in the southeast and northwest sectors (fig.11) and produced a residual that is more suitable for high-resolution mapping of magnetic boundaries. Relatively longer wavelength anomalies emphasizing deep regional-scale magnetic anomalies are shown as long linear pattern (NE-NW trend) in fig.11. Thus, changes in depth to magnetic basement in the study area also reveal a wide variety of magnetic patterns. The anomaly patterns of the same domain does not necessarily imply basement of similar lithologies but suggests sources with similar magnetic dimensions and properties. The white lines in figs. 10 and 11 are lineaments which manifest profound discontinuities in the magnetic basement and reflect continental scale geologic features. The remarkable steeper than normal horizontal gradient having a linear trend of the anomalies also suggests structural style (strike-slip displacement) while the discrete anomalous bodies, circular and lenticular in shape are intrusions and faulted basement blocks. Some of the intrusions are mafic plutons due to their high susceptibilities. Direct correlation of the magnetic patterns with surface geology in this study was hindered by thick post-rift sedimentary cover. 


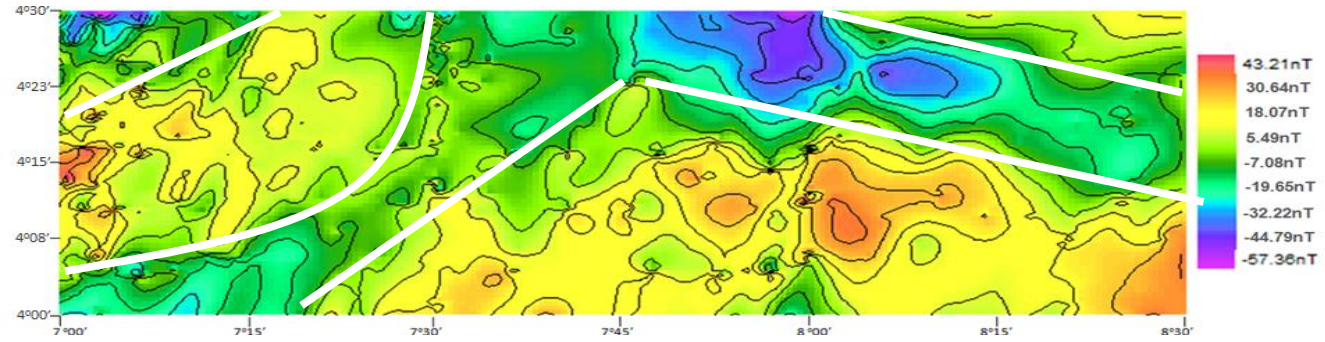

Fig.10 Filtered data showing domains of different geophysical characteristics separated by structural boundaries. The inferred structural boundaries are indicated with white lines.

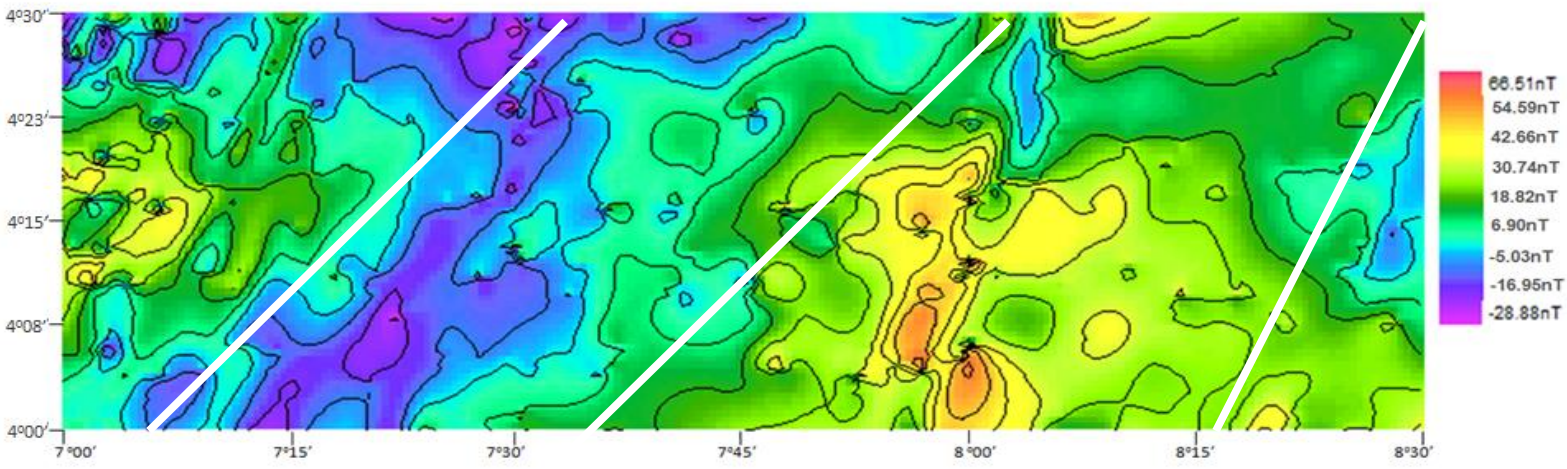

Fig.11 Filtered data characterized partly by short wavelength anomalies and partly by longer wavelength anomalies. White lines used to partition the data are accommodation zones which correspond to edges of structures

Combining the filtered data with other data sets such as the subsurface structural models and magnetic basement structure map, it is equivocally clear that the N-S trending anticlines, troughs and arches lie along or near the boundaries (lineaments). The geometries of the gradients along the flanks of the magnetic anomalies suggest plutons that developed in association with structures/faults that can be ascribed to South-Atlantic magnetic lineament. Thus, the examination of the filtered maps may be significant in evaluating boundaries of generalized tectonic provinces each revealing structures of similar trend and geophysical characteristics. Overall inspection of the filtered data sets reveals the bulk structure of the upper crust, where the brittle faults mainly reside. The brittle faults usually propagate into the sedimentary sequence where their effects are expressed on the distribution of modern surface lineaments which are targets in hydrocarbon exploration.

\section{Three-Dimensional Modeling Of The Residual Magnetic Field}

Forward modelling was carried out to obtain magnetization parameters such as remanence and susceptibility. Geometry of the anomalous sources was also obtained from forward modeling; the geometry which takes the form of step-like structure consists of contact between large igneous bodies and uplifted blocks at the site of fault such as a horst-graben. That is horst with intervening graben structures caused by extensional tectonics in the Niger delta. The physical properties and geometry of the sources are primary exploration risk parameters. Thus, we carried outs complete quantitative interpretation of the magnetic data which estimated three types of information about sources of geologic interest: the depth, dimension and the contrast in the relevant physical properties. The most significant parameter in this study is depth to geologic sources because basement structure inferred from magnetic depth estimates provides insight into the evolution of more recent sedimentary features such as minibasin compartmentalization, localization of reservoir-bearing structures in areas where the inherited basement fabric/architecture has affected either continuously or episodically basin evolution and development [29]. The forward approach is direct modelling which transform the variations reflected by potential field data as shown by the residual potential anomaly mapping to a convenient subsurface geological setting [30]. Due to the fact that potential field modelling suffers from non-uniqueness in determination of the source parameters from its field data because several earth models can produce the same magnetic response, we used simple bodies to reduce ambiguity. Thus, we adopted the algorithm of [31] based on magnetic anomalies due to rectangular prism-shaped bodies. This method met our objective because it considered anomalies due to induction in the earth's field and remanent magnetization. To further reduce ambiguity in interpretation we erected a model based on the geologic knowledge (passive rift - related basin of 
Southern Atlantic margin) of the Niger delta and since there is no control other than magnetic data we modified geometry and kept susceptibility constant during modeling [32].

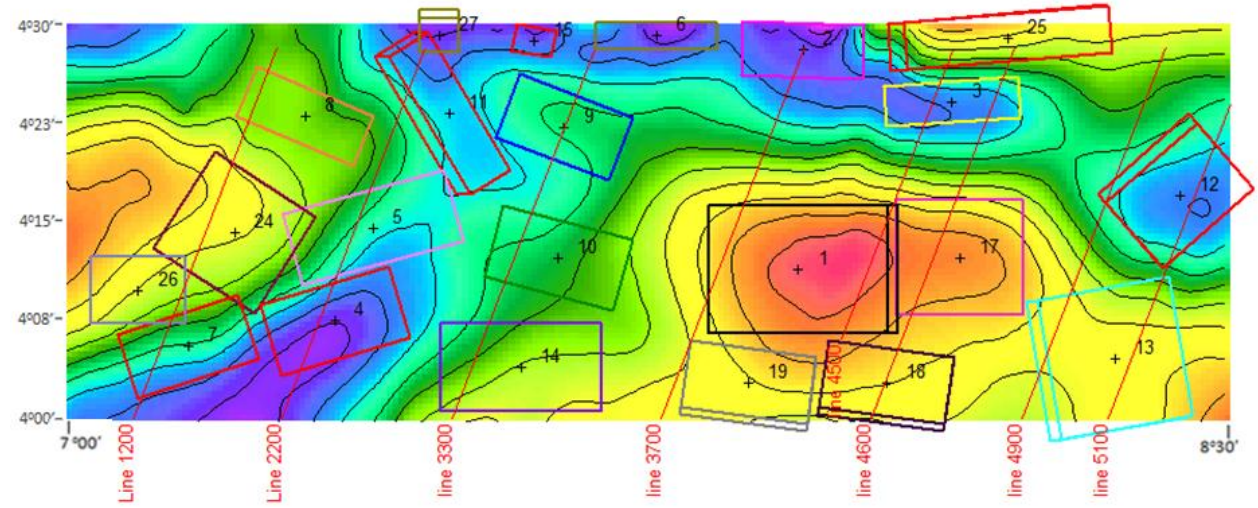

Fig. 12 Location of profile lines $1200,2200,3300,3700,4500,4600,4900$ and 5100 on the residual magnetic field

To estimate/interpret basement structure via magnetic depth estimate and provide a more complete understanding of critical first-order basin exploration parameters [29], eight magnetic profiles (fig. 12) were modelled. Modelling of profile line 2200 (fig.13a) showed that the magnetic signature is as a result of both structural and lithologic changes. The signature is dominated with magnetic high and this is a case of negative magnetic anomaly that leads to a magnetic high. The subsurface model is a 3-D magnetic imaging of block fault structure which is characteristic of rift setting. The hanging-wall block (body4) has a susceptibility of 0.0050SI. The depth to the top of this basement block is $5,800 \mathrm{~m}$. The foot-wall basement block (body5) is $9000 \mathrm{~m}$ deep. Thus, over this basement block is a $9 \mathrm{~km}$ sedimentary fill, suggesting a $20 \mathrm{~km}$ extended graben structure that consists of main depocentre that are separated by intra-rift horsts. The sinked block exhibits anisotropic susceptibilities of $\mathrm{ka}=0.0080 \mathrm{SI}, \mathrm{kb}=0.004 \mathrm{SI}$ and $\mathrm{kc}=0.004 \mathrm{SI}$, probably due to the normal fault and development of local fractures. Therefore, geologic sources in the subsurface model exhibited anisotropic susceptibilities and remanent magnetization as shown in table1 ranging from positive to negative values. This in combination with structural variation at depth has strongly affected the shape of the magnetic anomaly patterns.

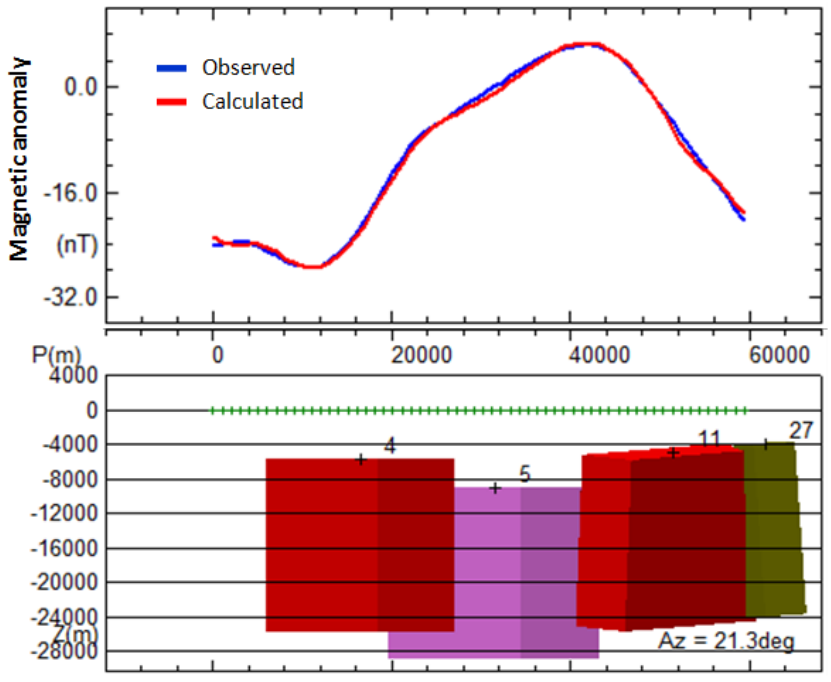

(a)

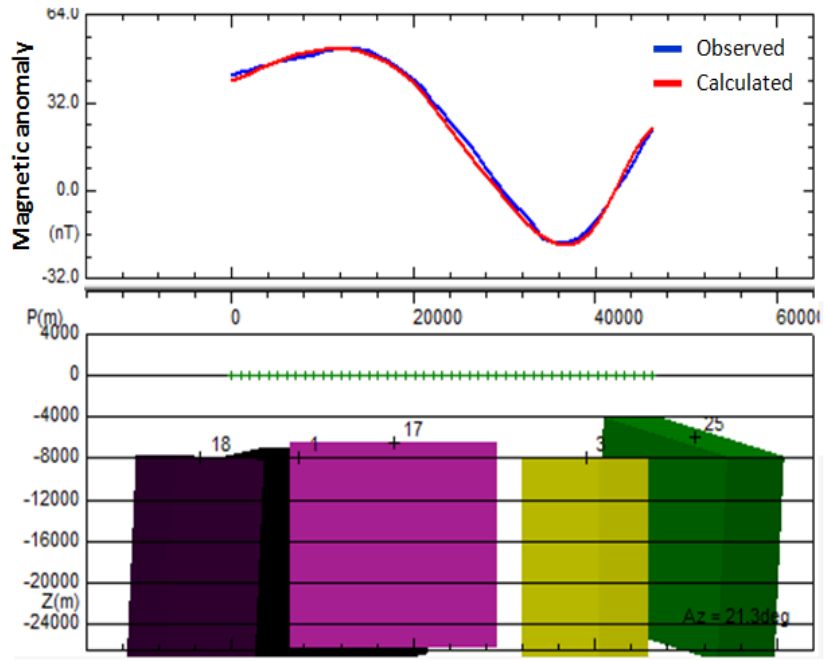

(b)

Fig. 13 Modelling of (a) profile Line 2200 and (b) profile Line 4500 displays the graben and horst structure in the basin. The magnetic high in (a) is a case of negative magnetic anomaly that leads to a magnetic high.

The subsurface models from profile lines 4500 (fig.13b) and 4600 (fig.14a) show a block-fault graben, $12 \mathrm{~km}$ wide. The graben resulted from subsidence of basement block (body 3) and flanked by two interconnected horsts (bodies 17 and 25). The horst and graben commonly form because of the interaction between synthetic and antithetic faults in rift system [33]. The little horizontal offset between the basement blocks 
(bodies 3 and 5) suggests that majority of the movement along fault is dip-slip in nature and that some of the normal faults suffered strike-slip movements in the evolution of the basin. The Steep faults bounding blocks may have accommodated alternating pulses of uplift, subsidence, tilting or strike-slip motion [34]. Thus, the two subsurface structural models from lines 2200 and 4500 show how the architecture of the basin and basin fill has been affected by the displacement geometry in the bounding normal fault systems. This is a first-order control on sedimentation and basin fill as a result of segmentation and structural relief due to extensional tectonics. The subsurface models from lines 1200 (fig.14b), 4500 and 4600 are dominated with sources with anisotropic susceptibilities in addition to negative susceptibility and characterized by both dip-slip and strike-slip motions (wrenching) between the basement blocks. These motions and physical properties is a pointer to weak zones probably due to depletion of magnetite and the combination of these motions is a regional segmentation commonly associated with group of structures known as accommodation and transfer zones. Accommodation zones correspond to belts of overlapping fault terminations and can separate either systems of synthetic and antithetic normal faults and attendant tilt-block domains. Accommodation zones can trend parallel, perpendicular or oblique to the extension direction. Transfer zones are discrete zones of strike-slip and obliqueslip faults that strike parallel or slightly oblique to extension direction and typically facilitate a transfer of strain between extended domains that are aligned along strike [35].

Another structural grain that must not be overlooked from the subsurface models is stepovers associated with the faulted blocks. Stepovers are places where sealing faults terminate or loose enough displacement that they loose their sealing properties. Hydrocarbon can more easily escape the graben system here than elsewhere along the system feeding shallow flanking structures capable of trapping small or large amounts of oil and gas [36].

Modelling of profile lines 3300 (fig. 15a) and 3700 (fig. 15b) clearly show intrabasement anomalous sources affecting the sedimentary section in step-like manner. The deepest trough $(9000 \mathrm{~m})$ centered over the basement block (body 9) produced a magnetic high due to its higher magnetic susceptibility. The magnetic susceptibility data in table 1 clearly demonstrate that the geobodies display magnetic anisotropy where in the induced magnetization is not parallel to magnetic field. This implies that for anisotropic bodies, a magnetic field in ka-direction will in general induce magnetization in other two directions ( $\mathrm{kb}$ and $\mathrm{kc})$.

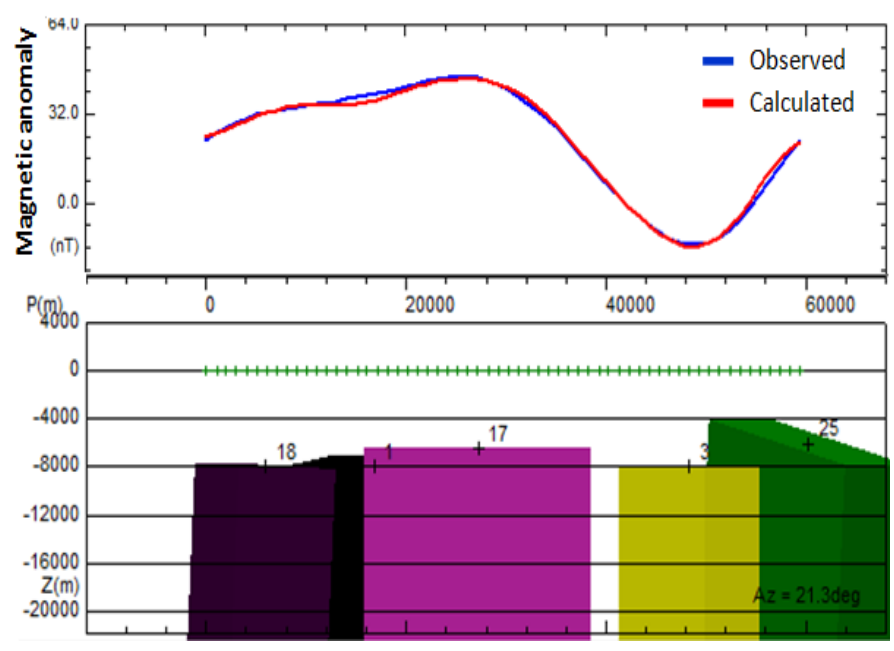

(a)

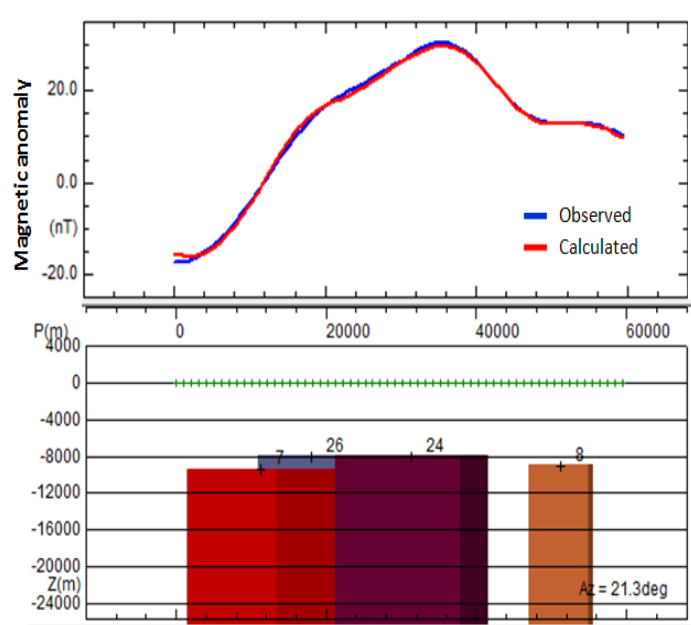

(b)

Fig. 14 Subsurface structural models from (a) Line 4600 and (b) line 1200. The basement blocks were subjected to both normal and strike-slip faults during the evolution of the basin with the sinked block in (a) covered with sedimentary thickness of $8,000 \mathrm{~m}$.

These susceptibility distributions are related to remanence and to the degree and direction of anisotropy. Thus, if there is no anisotropy on any scale, then there can be no remanence. Interpretation of profile line 3700 shows compositional changes between intrabasement blocks (19 and 1). The depth to the top of the adjacent basement block (body 2) is $10,000 \mathrm{~m}$ suggesting a thick sedimentary trough. This is a depocenter correlating positively with magnetic low in the northeastern sector of the study area and it is effective and probably most advanced thermal hydrocarbon generation site. The lithologic contacts from the models are often loci of structural disturbance (figs.16a and 16b) and the lithologic variations in magnetic basement generally show anomalies with highest amplitude. However, the magnetic signatures exhibited low amplitude due to the moderation of the amplitude owing to thick sedimentary sequence and presence of basement structure. That is, large amplitude 
anomalies will be observed where there is no basement structure. The Tertiary sedimentary fill on the intrabasement bodies are assumed to be non-magnetic and to produce little or no change in magnetic field.

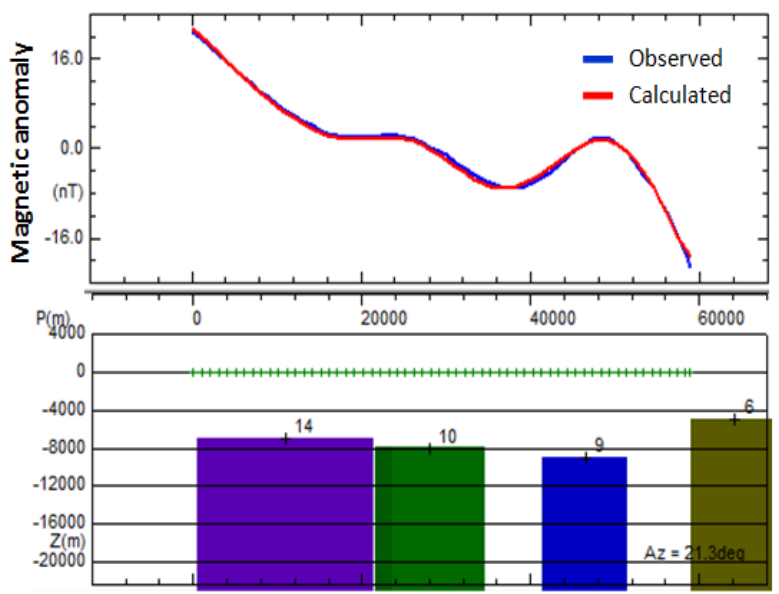

(a)

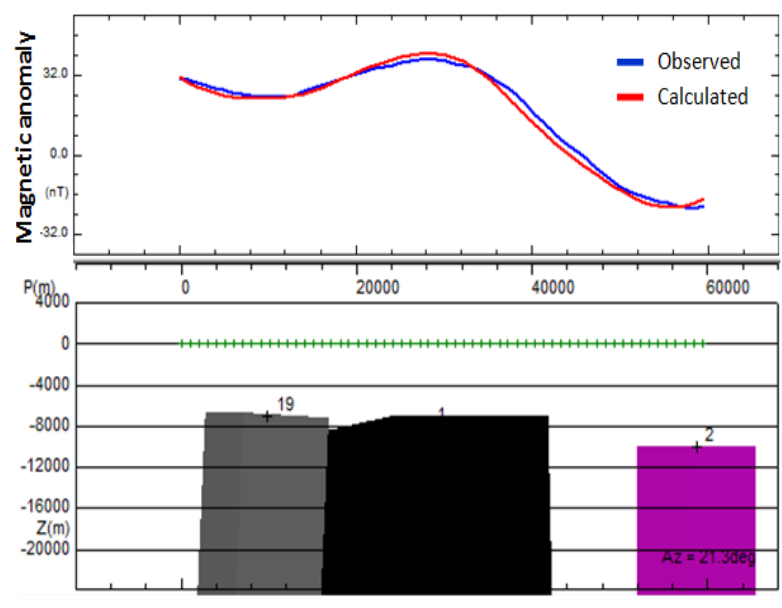

(b)

Fig. 15 Modelling of (a) Line 3300 and (b) Line 3700 revealed step-like structures which show sudden changes in magnetic response and lithologic changes within the basement blocks

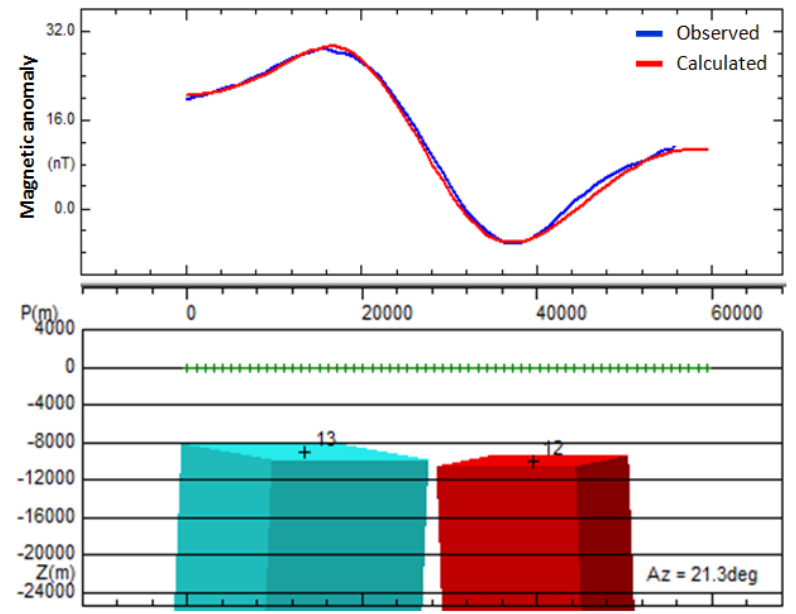

(a)

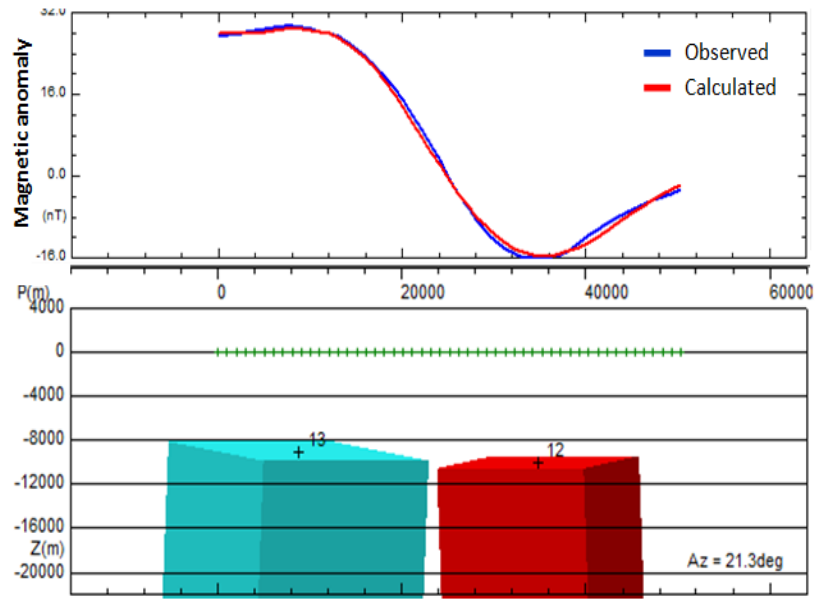

(b)

Fig. 16 Subsurface structural models from (a) Line 4900 and (b) Line 5100 show intrabasement sources with zones of lithologic contacts. The contacts are loci of structural disturbance.

Table 1. Model parameters. Ka, $\mathrm{kb}$ and $\mathrm{kc}$ are susceptibilities in three orthogonal directions

\begin{tabular}{|llllll|}
\hline Body & $\begin{array}{l}\text { Depth } \\
(\mathbf{m})\end{array}$ & $\begin{array}{l}\text { Width } \\
(\mathbf{m})\end{array}$ & Length $(\mathbf{m})$ & Susceptibility (SI) & $\begin{array}{l}\text { Remanence } \\
(\mathbf{A} / \mathbf{m})\end{array}$ \\
\hline 7 & 9500 & 10000 & 19000 & $\begin{array}{l}\text { Ka: } 0.00000 \\
\text { Kb: } 0.00000\end{array}$ & - \\
& & & & Kc: 0.02700 & \\
\hline 26 & 8000 & 10000 & 14000 & $\begin{array}{l}\text { Ka: } 0.00000 \\
\text { Kb: } 000000\end{array}$ & 0.2000 \\
& & & Kc: 0.01300 & \\
\hline 24 & 8000 & 17000 & 18000 & $\begin{array}{l}\text { Ka: } 0.00700 \\
\text { Kb: } 000000\end{array}$ & 0.2000 \\
& & & & Kc: 0.02800 & \\
\hline 8 & 9000 & 8000 & 19000 & $\begin{array}{l}\text { Ka: } 0.01100 \\
\text { Kb: } 0.01799\end{array}$ & 0.2000 \\
& & & & Kc: 0.01100 & \\
\hline 4 & 5800 & 11000 & 20000 & K: 0.00500 & - \\
\hline
\end{tabular}




\begin{tabular}{|c|c|c|c|c|c|}
\hline 5 & 9000 & 11000 & 25000 & $\begin{array}{l}\text { Ka: } 0.00800 \\
\text { Kb: } 0.00400 \\
\text { Kc: } 0.00000\end{array}$ & - \\
\hline 11 & 5000 & 7000 & 24000 & $\begin{array}{l}\text { Ka: } 0.02200 \\
\text { Kb: }-0.00700 \\
\text { Kc: } 0.00000\end{array}$ & - \\
\hline 27 & 4000 & 5000 & 6000 & $\begin{array}{l}\text { Ka: } 0.01200 \\
\text { Kb: } 0.00000 \\
\text { Kc: }-0.00800\end{array}$ & - \\
\hline 14 & 7000 & 13000 & 24000 & $\begin{array}{l}\text { Ka: } 0.00899 \\
\text { Kb: } 0.00000 \\
\text { Kc: } 0.00200\end{array}$ & -0.3000 \\
\hline 10 & 8000 & 11000 & 20000 & $\begin{array}{l}\text { Ka: } 0.00400 \\
\text { Kb: } 0.00000 \\
\text { Kc: } 0.00300\end{array}$ & -0.2000 \\
\hline 9 & 9000 & 10000 & 18000 & K: 0.00899 & -0.2000 \\
\hline 10 & 5000 & 4000 & 18000 & K: 0.01100 & 0.1200 \\
\hline 14 & -7000 & 10000 & 19000 & $\begin{array}{l}\text { Ka: } 0.00000 \\
\text { Kb: } 0.00000 \\
\text { Kc: } 0.00600\end{array}$ & -0.1000 \\
\hline 19 & 8000 & 19000 & 27000 & $\begin{array}{l}\text { Ka: } 0.00000 \\
\text { Kb: } 0.00000 \\
\text { Kc: } 0.02000\end{array}$ & -0.2000 \\
\hline 1 & 10000 & 8000 & 18000 & $\begin{array}{l}\text { Ka: } 0.00899 \\
\text { Kb: } 0.00000 \\
\text { Kc: } 0.00000\end{array}$ & 0.1000 \\
\hline 18 & 8000 & 10000 & 19000 & $\begin{array}{l}\text { Ka: } 0.00000 \\
\text { Kb: } 0.00000 \\
\text { Kc: } 0.02300\end{array}$ & -0.1000 \\
\hline 17 & 6500 & 17000 & 19000 & $\begin{array}{l}\text { Ka: } 0.00000 \\
\text { Kb: }-0.00100 \\
\text { Kc: } 0.01500\end{array}$ & -0.1000 \\
\hline 3 & 8000 & 6000 & 20000 & $\begin{array}{l}\text { Ka: } 0.00899 \\
\text { Kb: }-0.01000 \\
\text { Kc: } 0.00100\end{array}$ & 0.1000 \\
\hline 25 & 6000 & 7000 & 31000 & $\begin{array}{l}\text { Ka: } 0.00000 \\
\text { Kb: } 0.00000 \\
\text { Kc: } 0.00500\end{array}$ & -0.2000 \\
\hline 13 & 9000 & 21000 & 20000 & $\begin{array}{l}\text { Ka: } 0.00000 \\
\text { Kb: } 0.00000 \\
\text { Kc: } 0.01850\end{array}$ & -0.1000 \\
\hline 12 & 10000 & 18000 & 13000 & $\begin{array}{l}\text { Ka: } 0.01300 \\
\text { Kb: } 0.01300 \\
\text { Kc: } 0.00000\end{array}$ & - \\
\hline
\end{tabular}

The magnetic modelling has identified the generating mechanisms (basement faults and lithologic contacts), extensions, physical properties of causative sources, wrenching, geometry of igneous plutons and most importantly depths to basement. In petroleum exploration the structural surface interpreted from magnetic depth estimate is often the best available approximation to the true crystalline basement configuration and basement depth (sedimentary thickness) is the primary exploration risk parameter. Estimate of basement depth are directly applicable to basin modelling such as rock volume estimation and thermal maturity application such as rock burial depth [29]. Fig. 17 (depth to basement map) gives insight to the compartmentalization of the study area into four minibasins. Sectors with purple, blue and green are the subasins while areas with orange, yellow and red are the structural highs (horst). Thus, the depth to basement map shows north-south trending basement horst with intervening graben structures. Reactivation of the rift-related normal faults gave rise to the basement uplift (horst). From the subsurface structural models and the depth to basement map, extensional block faulting with graben flanked by step-faulted horst predominate in the Niger delta. The graben (prominent basement synclines) are in this study viewed as favorable sites for source rock development and the prominent highs suggests thinner source rock development which may be collecting areas for early hydrocarbon migration [37]. In the study area, sediment thickness appears to be higher in the eastern and western sectors. Thus, basement framework ultimately determines the depocenters and sedimentary fairways. Fig. 17 shows how the study area which is a passive margin basin is clearly segmented along strike into discrete subbasins separated by basement highs and sediment is thinner over the basement highs. That is, the depocenters (minibasins/subasins) are segmented from the structural highs by accommodation zones which are largely responsible for the regional segmentation of the extended terranes. Accommodation zone is an area of complex structure and such zone may be preferred areas 
of fracturing and development of small scale structures which may be prospective. This tectonic interpretation can be used to define details within known productive areas as well as to point out analogous locations for exploration [38].

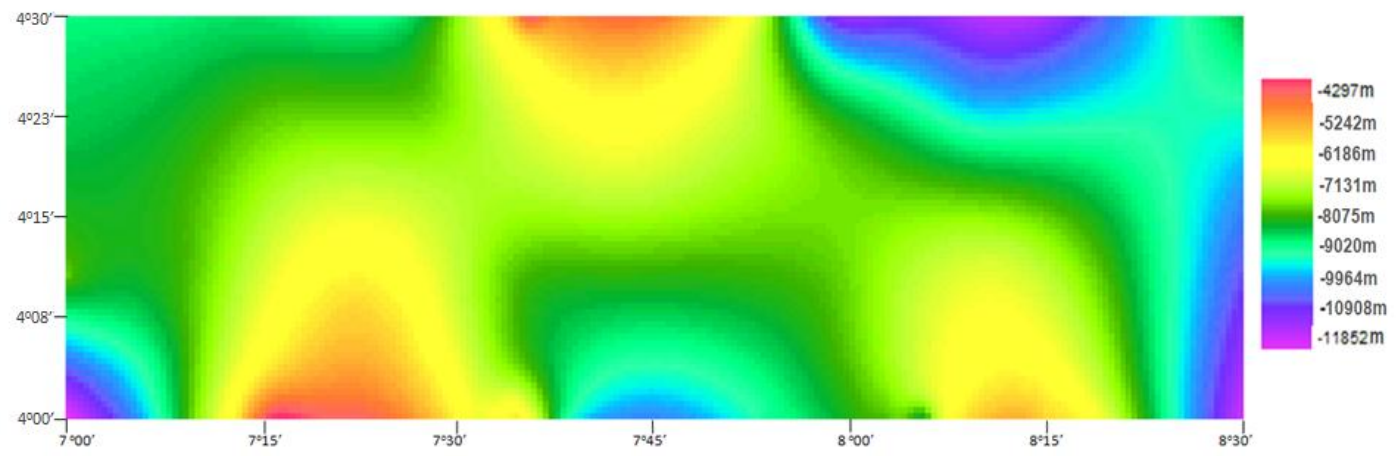

Fig.17 Depth to basement map showing typical segmentation of the study area along strike into discrete subbasins separated by basement highs. Each minibasin correspond to discrete rift segments and the highs correspond to accommodation zones

\section{Discussion And Conclusion}

Analyses of public domain regional magnetic field data from the Niger delta basin show that the basement fabric can be unraveled accurately and inexpensively. The application of residual magnetic field data, derivative filtering and wavelength filtering revealed lineament that trend in different direction. The lineaments in the data sets are magnetic boundaries of basement structural blocks, fault/shear zones and lithologic contacts. These boundaries of the basement blocks affected deposition in the delta and are defined by lineaments in the magnetic data sets. Thus, magnetic anomaly maps can provide the template of deformation patterns and structural architecture in the basement that can be used to examine basement influence on the sedimentary section [3]. Enhanced magnetic data sets in the study area showed new details of the structural grain of the basement underlying the Niger delta and identified some previously unrecognized magnetic lineament. For example, the analytic signal and directional derivative data set in $\mathrm{x}$ direction and first vertical derivative show major structural trends in the N-S direction which has created repeated basement horsts and grabens. Basement fault reactivation is now recognized as an important control in sedimentation and fault propagation in intercratonic basins [39].

The faulted basement blocks, shear zones and intrabasement compositional changes are clearly revealed in the analytic signal map, derivative maps and the 3-D subsurface models. Thus, one of the greatest benefits of the analyzed magnetic data sets is that prior to committing an expensive seismic programme in a difficult exploration terrain one can perform detailed magnetic data analyses on the readily available magnetic data using new imaging techniques to increase geological understanding of the area. This may affect the acquisition parameters and the orientation of any $3 \mathrm{D}$ seismic survey being considered [40]. The area studied is composed of clastic sequence of over $10,000 \mathrm{~m}$ as shown from the depth to basement map. Thus, there is positive correlation in both trend and location between the deep basement troughs and the Tertiary depocenters which has been depended on the balance between the rate of sedimentation and the rate of subsidence. This balance and the resulting sedimentary patterns appear to have been influenced by the structural configuration and tectonics of the basement. The depocenters continued to develop during the Late Miocene and Pliocene. In particular, the Oligocene and Early Miocene depocenters seem to correspond to the low areas between basement blocks and hydrocarbons are concentrated along the updip edge of these depocenters adjacent to the major growth faults where viable structural traps predominate [17]. We, therefore, in this study opine that the exploration of the deep basement in the Niger delta is critical to hydrocarbon exploration and depart from the idea that magnetic method of geophysical exploration is merely used for reconnaissance studies. At least the results from this study show that the subbasins are generally well known and overall deltaic wedge and associated down faulting in the basement especially in the initial stages of formation of the delta are prominent. All this support the fact that exploration efforts have shifted towards the use of non-seismic exploration methods for regional and prospect level quantification before drilling. The structural fabric of the basement and overlying Tertiary sedimentary section interpreted from the transformed magnetic data and subsurface models are equivocally inherited from the early rift architecture which controlled the distribution and thickness of the Tertiary sediments. The rifting probably enhanced erosion and weathering and created depositional accommodation space when the faulted basement blocks sinked. Thus, extensional block faulting shown in the subsurface models competed with erosion and deposition within rift-related system of the delta. 
The outline of the depocenters seems to reflect an interaction of the tectonic directions (NE-SW, N-S and E-W) in the delta. The NE-SW basement trends appear to indicate possible extensions within the African continent of the Charcot and Chain oceanic (transform) fracture zones and in combination with N-S structures may have propagated through sedimentary cover by episodic reactivation induced by changes in the regional stress field in the delta. Therefore, understanding the regional structural characteristics of the buried basement in the Niger delta is critical first order basin exploration approach which has been applied to other basins of the world. For example, [9] reported that all the known oil fields of Saudi Arabia and its offshore are related to four major directions of basement faulting, namely N-S, NE-SW, NW-SE and E-W. Thus, understanding the basement both as a surface and through fault planes provided in 3D, give information about the tectonic history, present day traps and the potential pathways of hydrocarbon [40].

[41], [42] and [43] demonstrated consistent growing evidence that some hydrocarbon traps may be systematically controlled by network of steep faults in the basement.. We used Bonga oil field (fig. 18) in the Niger delta to establish relationship between basement framework (fig. 17) and oil and gas fields.

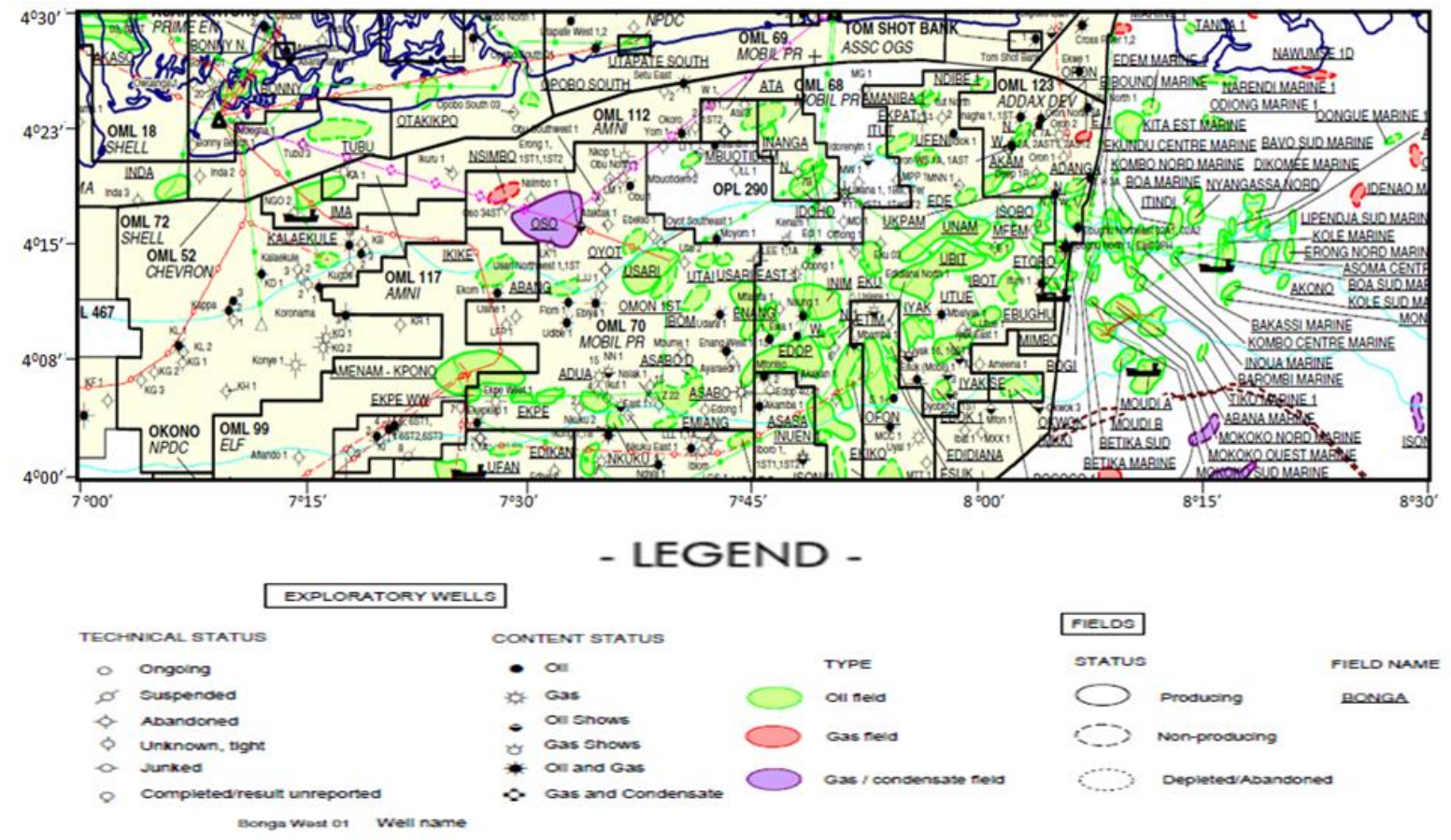

\section{Fig. 18 Exploratory wells, oil and gas fields in Bonga oil field (Source: Global Exploration and Production service).}

The correlation shows that most of the oil fields are either located on steep/faulted flanks of the basement or on top of basement structural highs. The oil fields trend mostly in the NE-SW (principal shear stress) and N-S directions and appear to coincide with areas of broad low amplitude magnetic anomalies. The gas/condensate fields in the southeast sector trend also in NE-SW and N-S directions. This coincidence of hydrocarbonreservoir trends with basement related magnetic field lineaments is of significant exploration interest and should stimulate further investigation in the delta. While two of the gas/condensate fields are on top of steep basement flanks one is located on basement trough. The relatively large gas/condensate field (OSO) located in the NW flank of the study area is on the basement structural high. In this sector one of the oil fields (TUBU) is aligned in E-W direction and where there is a major segmentation between the horst and graben in the eastern sector show a N-S trend of the oil fields. In the extreme south west sector some exploratory wells have been abandoned, junked or suspended (areas of less lineament development) while some producing exploratory wells are located on top of basement structural highs and steep basement high. Three producing exploratory wells are located in basement lows. Oil blocks (oil mining lease and oil prospecting lease) allocation in Bonga field shows that five blocks, namely OML 18 (Shell), OML72 (Shell), OML52 (Chevron), OML 123 (Addax Dev) and OML70 (Mobil) are located in basement structural low. In steep and faulted flanks of the basement are located OML99 (Elf), OML112 (AMNI) and OML68 (Mobil). OML117 (AMNI), OML69 (Mobil) and OPL290 are located on top of basement structural highs. Many basins located in Agentina, Peru, Ecuador, the Austrian Vienna basin, Yugoslavia, the Hungarian plains, several in the former USSR, on/offshore China and Northwestern Sumatra, Western and eastern offshores of India have oil/gas production associated to basement structure [44]. 


\section{References}

[1] J. D. Fairhead, Regional tectonics and basin formation: The role of potential field studies in Phanerozoic, Regional Geology of the world, 12, 2012, 330-341.

[2] M. Smith and P. Mosley, Crustal heterogeneity and basement influence on the development of the Kenya rift, East Africa, Tectonics, 12(2), 1993, 591-606.

[3] M. Ross, D. Eaton, Basement reactivation in the Alberta basin, Bulletin of Canadian Petroleum Geology, 47 (4), 1999, $391-411$.

[4] O. Elebiju, G. R. Keller and K. J. Marfurt, Investigation of links between Precambrian basement structure and Paleozoic strata in the Fort Worth basin, Texas, U.S.A., using high-resolution aeromagnetic (HRAM) data and seismic attributes, Geophysics, 75 (4), $2010157-168$

[5] H. V. Lyatsky, D. I. Pana and M. Grobe, Basement structure in Central and Southern Alberta: Insights from Gravity and Magnetic maps, Alberta Energy and Utility Board/Alberta Gelogical Survey (EUB/AGS) special report 72, 2005.

[6] M Dentith, D. R. Cowan and L. A. Tompkins, Enhancement of subtle features in aeromagnetic data, Exploration Geophysics, 31, 2000, 104-108.

[7] A. L. Piskarev and M. Y. Tchernyshev, Magnetic and gravity anomaly patterns related to hydrocarbon fields in northern West Siberia, Geophysics, 62 (93), 1997, 831-841.

[8] A. Mohammed, K. Palanivel and C. J. Kumanan, Significance of surface lineament for oil and gas exploration in part of Sabatayn Basin-Yemen, Journal of Geography and Geology, 2(1), 2010, 119-128.

[9] H.S. Edgell, Basement tectonics of Saudi Arabia as related to oil field structures. In: M. J. Rickard etal (eds.), Basement tectonics 9, Kluwer Academic Publishers, Dordrecht, 1990, 169-193.

[10] B. L. Crawford, P. G. Betts and L. Ailleres, An aeromagnetic approach to revealing basement structures and their role in the Proterozoic evolution of the Wernecke Inlier, Yukon Territory, Canada, Tectonophysics, 490, 2010, 28-46

[11] M. Alexander, J. C. Pratsch and C. Prieto, Under the northern Gulf basin: basement depths and trends, Paper presented at the 1998, Society of Exploration Geophysicists Sixty-Eight Annual Meeting, New Oleans, 1998.

[12] K. C. Short, A. J. Stäuble, Outline of geology of Niger Delta, American Association of Petroleum Geologists Bulletin, 51, 1965, $761-779$.

[13] E. J. Frankl, E. A. Cordry, The Niger Delta oil province: Recent developments onshore and offshore, Proceedings of World Petroleum Congress, 1967, 195-209.

[14] G. I. Knox and F. M. Omatsola, Development of the Cenozoic Niger Delta in terms of the 'Escalator Regressions' model and impact on hydrocarbon distribution, Proceedings of KNGMG symposium coastal Lowlands, Geology and Geotechnology, Kluwer Academic Publishers, 1987, 181-202.

[15] J. Mascle, J., Submarine Niger Delta: Structural framework, Journal of Mining Geology, 1975, 13, 1-2.

[16] T. R. A. Reijers, Stratigraphy and sedimentology of the Niger Delta, Geologos, 17(3), 2011, 133-162.

[17] B. D. Evamy, J. Haremboure, P. Kamerling, W. A. Knaap, F. A. Molloy and P. H. Rowlands, Hydrocarbon habitat of Tertiary Niger Delta, American Association of Petroleum Geologists Bulletin, 62, 1978, 277-298.

[18] M. L. W. Tuttle, R. R. Charpentier and M. E. Brownfield, The Niger Delta petroleum system: Niger Delta province, Nigeria, Cameroun and Equatorial Guinea, Africa, U. S. Geological Survey Open-file Report-99-50-H, 1999, 31P.

[19] K. J. Webber, Sedimentological aspects of oil fields in the Niger delta, Geologie EN MijnBouw, 50(3), $1971,559-576$.

[20] Y. Li, D. W. Oldenburg, Separation of regional and residual magnetic data, Geophysics, 63(2), 1998, 431-439.

[21] W. R. Roest, J. Verhoef, M. Pilkington, Magnetic interpretation using the 3-D analytic signal, Geophysics, 57, 1992, 116-125.

[22] R. I. Blakely, Potential theory in gravity and magnetic applications (Cambidge, Cambridge University Press, 1996).

[23] V. J. S. Grauch and L. Cordell, Limitations of determining density or magnetic boundaries from the horizontal gradient of gravity or pseudogravity data, Geophysics, 52, 1987, 118-121.

[24] B. D. Verduzco, J. D. Fairhead, C. M. Green, C. MacKenzie, New insight into magnetic derivatives for structural mapping. The Leading Edge, 23, 2004, 116-119.

[25] GETECH GROUP., 2007: Advanced Processing and Interpretation of Gravity and Magnetic Data. Retrieved from http://www.getech.com/services/advancedprocessingandinterpretation.pdf

[26] M. N. Nabighian, The analytic signal of two-dimensional magnetic bodies with polygonal cross-section: Its properties and use for automated anomaly interpretation, Geophysics, 37, 1972, 507-517.

[27] N. Debeglia, J. Corpel, Automatic 3-D interpretation of potential field data using analytic signal derivatives, Geophysics, 62(1), 1997, 87-96

[28] S. P. Gay Jr., Basement control of selected oil and gas fields in Kansas as determined by detailed residual aeromagnetic data In: Geophysical Atlas of selected Oil and Gas fields in Kansas, Kansas Geological Survey Bulletin, 237, 1995, 10-16.

[29] X. Li, On the use of different methods for estimating magnetic depth, The leading edge: The meter reader, 22(11), 2003, 10901099.

[30] L. Brimich, A. Khalil, P. Kordik, M. Mekkewi, M. EL-Bohoty, M. K. Refai, A. K. A. Kader, Active subsurface structures at Fayoum- Cairo district, Northern Western Desert Egypt, as deduced from magnetic data, Contributions to Geophysics and Geodesy, 41(4), 2011, 329- 351.

[31] B. K. Bhattacharyya, Magnetic anomalies due to prism-shaped bodies with arbitrary polarization, Geophysics, 29(4), 1964, 517531.

[32] D. E. Bird, Primer: Interpreting magnetic data, American Association of Petroleum Geologist Explorer, 8(5), 1997, 18-21

[33] B. A. V. Pluijm, S. Marshak, Earth structure: An introduction to structural Geology and tectonics, (New York, W. W. Norton and company, 2004)

[34] D.J. Edwards and R.J. Brown, A geophysical investigation of basement control on reef growth. Alberta Basement Transects Workshop (March 1-2), Lithoprobe Report \#31, G.M. Ross (ed.), 1993, 18-28. Lithoprobe Secretariat, University of British, Columbia,Vancouver.

[35] J. Faulds, R. J. Varga, The role of accommodation zones and transfer zones in the regional segmentation of extended terranes. Gelogical Society of American (Special Paper 323), 1998, 1-45.

[36] H. Fossen, R. A. Schultz, E. Rundhvde, A. Rotevatn and S. Buckley, Fault linkage and graben stopovers in the Cayonlands (Utah) and the North Sea Viking Graben, with implications for hydrocarbon migration and accumulation. The American Association of Petroleum Geologists, 94(5), 2010, 597-613.

[37] M. Alexander, C. Prieto, B. Radovich, Basement structural analysis: Key in deep shelf plays. The American oil and gas Reporter, 2003, Retrieved from http www.igcworld.com 
[38] R. I. Gibson, Interpretation of Rift-stage Faulting in the West Siberian Basin from Magnetic Data. Geologic applications of Gravity and Magnetics: case Histories: In I. Gibson and P. S. Millegan. (Eds.) SEG Geophysical Reference No.8 and AAPG Studies in Geology, 1998, (No. 43, pp. 59-63).

[39] J. I. Boyce, W. A. Morris, Basement - controlled faulting of Paleozoic strata in Southern Ontario, Canada: new evidence from geophysical lineament mapping. Tectonophysics, 353 (1), 2002, 151-171.

[40] M. E. Jacques, J. M. Parsons, A. D. Price, and D. M. Swhwartz, Draw upon recent work to provide evidence as to why gravity and magnetic survey data can still provide vital geological clues for oil and gas exploration. First break, 21, 2003, 57-62.

[41] D. I. Edwards, H.V. Lyatsky, R.J. Brown, Regional interpretation of steep faults in the Alberta Basin from public-domain gravity and magnetic data: an update, Canadian Society of Exploration Geophysicist Recorder, 1998, 15-24.

[42] R.M.P. Jones, Basinal isostatic adjustment faults and their petroleum significance, Bulletin of Canadian Petroleum Geology, 28, $1980,211-251$

[43] R.G. Greggs, D.H. Greggs, Faul-tblock tectonism in the Devonian subsurface, Western Canada Basin, Journal of Petroleum Geology, 12, 1989, 377-404.

[44] C. Prieto, C. Pratsch, Gulf of Mexico study links deep basement structure to oil fields: Demonstrating deep structural control, Intergrated Geophysics Corporation Footnotes series on Interpretation, 2000. 